\title{
Identification of cellular immunoglobulins in chronic lymphocytic leukaemia by immunoperoxidase staining
}

\author{
GERALDINE M MARKEY, ROBYN E MCCONNELL, HD ALEXANDER, TCM MORRIS, \\ JH ROBERTSON
}

From the Department of Haematology, the Laboratories, Belfast City Hospital, Lisburn Road, Belfast BT9 $8 A B$

SUMMARY An indirect immunoperoxidase technique has been used for visualisation of cellular immunoglobulins in chronic lymphocytic leukaemia. Baker's formol calcium was used as fixative. Monoclonal light and heavy chain patterns were demonstrated in 24 out of 27 cases. Only one case did not have any demonstrable immunoglobulins.

The presence of $\alpha$ or $\gamma$ heavy chain immunoglobulin isotypes in leukaemic lymphocytes was found to be related to low mouse rosetting capacity $(\mathrm{p}<0 \cdot 05)$.

The demonstration of a clone of cells producing only one heavy and one light immunoglobulin (Ig) chain is the hallmark of a neoplastic growth of lymphocytes such as occurs in B type chronic lymphocytic leukaemia (B-CLL). Fluorochrome labelled antibodies are widely used to demonstrate such surface immunoglobulins on living B-CLL cells. Attempts to use immunoperoxidase procedures for immunoglobulin demonstration in CLL have to date indicated a lesser degree of sensitivity of this method. Thus Mason et al ${ }^{1}$ using an immunoperoxidase "sandwich" on fixed cells found that only five of 28 cases of CLL showed positive labelling and Laurent et $a l^{2}$ only found positivity for immunoglobulin $\mu$ in significant numbers in five of 10 cases of CLL when fixed cells were used. Nevertheless, Knowles et $\mathrm{al}^{3}$ in a study using both living and fixed lymphocytic cells found that immunofluorescence and immunoperoxidase methods gave comparable results. In this paper we describe our findings in 27 cases of CLL using an indirect immunoperoxidase technique on cells fixed with Baker's formol calcium.

\section{Material and methods}

\section{PATIENTS STUDIED}

Twenty-seven patients (17 male, 10 female) with B-CLL were investigated. The diagnosis of CLL was based on clinical and haematological grounds, all patients having peripheral blood lymphocytosis and bone marrow infiltration. Any patient with cleaved lymphocytes in the peripheral blood was excluded from the study.

MONONUCLEAR CELL SEPARATION ANI) PREPARATION OF CYTOSPINS

Mononuclear cells were separated from heparinised blood over Ficoll-Paque and the cells at the interface were washed three times in Hank's buffered salt solution (HBSS) at $37^{\circ} \mathrm{C}$ to remove adsorbed immunoglobulins. Sheep erythrocyte rosette $\left(E^{4} R\right)$ tests were peformed by the method recommended in the WHO-IRAC Report ${ }^{4}$ for T cell enumeration. Mouse rosette (MR) tests were performed by the method of Stathopoulos and Elliott. ${ }^{5}$ Normal values for this laboratory are $2 \%$ or less.

The concentration of the mononuclear cell suspension was adjusted to $1 \times 10^{\circ}$ cells $/ \mathrm{ml}$ and cytospins made from each sample using a Shandon Elliott cytocentrifuge. The cytospins were rapidly air-dried, wrapped in aluminium foil ${ }^{\circ}$ and immediately stored at $-20^{\circ} \mathrm{C}$. Myeloma cells $(\operatorname{Ig} \gamma \kappa)$ and lymphoma cells from patients with monoclonal serum immunoglobu$\operatorname{lin}(\operatorname{Ig} \alpha \kappa, \operatorname{Ig} \gamma \lambda$ and $\operatorname{Ig} \mu \kappa)$ were similarly prepared and stored for control purposes.

TRYPSINISATION OF CELLS

An additional sample from one patient (Table 2, case 2) who was found to have CLL, RAI Stage (), in 1976 and whose condition has not shown any evidence of progression in the meantime, was obtained 
and the mononuclear cells separated and washed as above. Trypsinisation was performed as described by Preud homme and Seligmann. ${ }^{7}$ In brief, an aliquot of the cells was incubated for $20 \mathrm{~min}$ at $37^{\circ} \mathrm{C}$ in Eagle's medium (supplemented with $15 \%$ fetal calf serum) to which trypsin was added at a concentration of $2.5 \mathrm{mg} / \mathrm{ml}$. After this, the cells were washed three times in PBS and incubated overnight in Eagle's medium. Cytospin preparations of the cells were made before and after trypsinisation and after incubation and stored as above.

ANTI-IMMUNOGLOBULIN ANTIBODIES AND PEROXIDASE CONJUGATED ANTIBODIES

Rabbit antihuman $\kappa, \lambda, \mu, \gamma$ and $\alpha$ chains were obtained from DAKO (Mercia Brocades Ltd) immunoglobulins as was horseradish peroxidase conjugated swine immunoglobulin to rabbit immunoglobulin. Rabbit antihuman $\delta$ chain antiserum was obtained from Nordic Immunoglobulins. The optimal dilution for each antibody was determined using cells from CLL cases (Nos $2 \& 4$ ) and the control myeloma and lymphoma cells. All antibody dilutions were made in phosphate-buffered saline (PBS) containing $1 \%$ ovalbumin and the dilutions used throughout the study are shown in Table 1.

\section{IMMUNOPEROXIDASE PROCEDURE}

Test and control slides were removed from the $-20{ }^{\circ} \mathrm{C}$ freezer on the morning of procedure, allowed to equilibrate with room temperature before removing the foil and then fixed in Baker's formol calcium for $4 \mathrm{~min}$. Fixation for longer than 4 min resulted in decreased positivity. After washing in PBS, slides were immersed in absolute methanol containing $0.3 \%$ hydrogen peroxide to block the endogenous peroxidase activity of any contaminating monocytes or polymorphonuclear leucocytes. They were again washed with PBS and blotted dry. Primary antibody was laid on the cytospin area for 30) min after which the slides were washed in PBS with continuous stirring for $20 \mathrm{~min}$, changing the PBS at five-minute intervals. Secondary peroxidase conjugated antibody was then laid on the cytospin area for $30 \mathrm{~min}$ with subsequent washing as above. The peroxidase stain was immediately performed using 3 amino 9 ethylcarbazole ${ }^{8}$ (Northeast Biomedical Laboratories) as substrate and counterstaining with Mayer's haematoxylin. The slides were mounted in glycerol saline and sealed with nail polish. Room temperature was maintained between 24 and $26^{\circ} \mathrm{C}$ throughout the period of incubation with primary and secondary antibodies because variation in the sensitivity of the procedure was found to occur when temperatures were below or above these levels. Positive and negative control cytospin prep- arations from the cases used to determine the optimal antibody dilutions were included with each batch of tests done. No deterioration of staining has been noted in these controls over a period of nine months storage at $-20^{\circ} \mathrm{C}$. Moreover, immunoglobulin identification has been possible using cytospins stored for 18 months.

The preparations were examined by conventional light microscopy using a Leitz Ortholux microscope with high resolution oil immersion objective. The whole cytospin was rapidly scanned and a minimum of 200 cells counted in each preparation.

\section{SERUM IMMUNOGLOBULIN ESTIMATION}

Results were available in 25 patients and depression of one or more serum immunoglobulins was present in all cases. Cellulose acetate electrophoresis in these 25 patients showed an $\mathrm{M}$ band $(\mu \kappa)$ in one
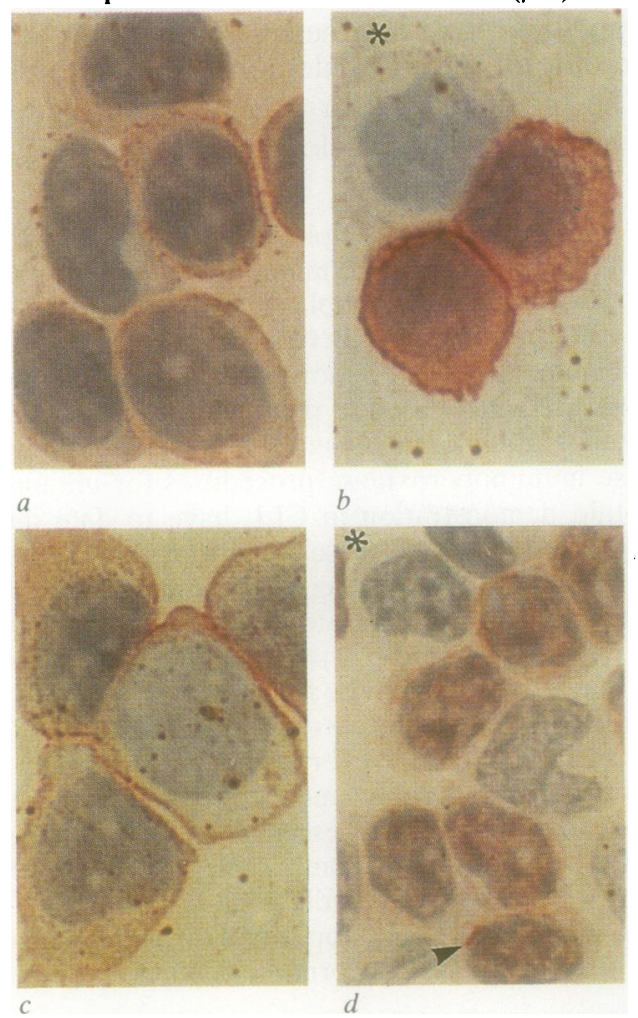

(a) Lymphocytes from patient 17: weak staining for $\lambda$ chains. $(\times 3150)$; (b) Lymphocytes from patient 2: strong $N$ staining for $\lambda$ chains with accentuation of staining at the cell margins. Asterisk indicates a negative lymphocyte.

( $\times 3150)$; (c) Lymphocytes from patient 4: moderately strong staining for $\kappa$ chains. One cell shows distinct staining at the cytoplasmic margin: two cells show diffuse staining. ( $\times 3150)$; (d) Lymphocytes from patient 22: weak staining. for $\mu$ chains. Arrow points to positive intracellular crystal. Asterisk indicates a negative lymphocyte. $(\times 3150)$. 
Table 1 Primary and secondary antibody dilutions for immunoperoxidase procedure

Rabbit antihuman

$\begin{array}{lllllll}\text { immunoglobulin chain } & \kappa & \lambda & \mu & \alpha & \delta & \gamma \\ \text { Dilution } & 1 / 150 & 1 / 150 & 1 / 10 & 1 / 10 & 1 / 40 & 1 / 80\end{array}$

Peroxidase conjugated

swine anti rabbit

immunoglobulins

Dilution

$\begin{array}{llllll}1 / 20 & 1 / 20 & 1 / 20 & 1 / 20 & 1 / 20 & 1 / 20\end{array}$

patient (No 4): electrophoresis of urine revealed the presence of Bence-Jones protein $(\lambda)$ in patient No 2 .

\section{Results}

Examples of our results in cases of CLL are shown in Figs a-c and demonstrate the range of positivity which we obtained. The end colour produced by the peroxidase reaction using aminoethylcarbazol as substrate is reddish brown. Two main patterns were observed. In the first, distinct brown staining of the cytoplasmic membrane was present combined with pale or light brown "cytoplasmic" staining. In the second, "cytoplasmic" staining was present without accentuation of the cell membrane. The first pattern was more common but quite often cells of each type were present in the same cytospin (Fig. c). Staining with anti $\operatorname{Ig} \mu$ antiserum generally gave stronger positive reactions than the light chain antisera. Fig. d shows weak staining with anti $\operatorname{Ig} \mu$ in patient 22 (Table 2) and also in this patient intracytoplasmic crystals $(\mu \lambda)$ were demonstrable in a small proportion of cells. The percentage of $E^{4} R$ found in each case was comparable to the percentages of negative cells shown by the antisera giving positive results and these negative cells could be clearly identified in the positively stained cytospins (Fig. b).

The percentages of positive cells with each antiserum in each patient are shown in Table 2 together with absolute lymphocyte counts, $E^{4} R, M R$ and treatment status. The absolute lymphocyte counts were raised in all but two patients at the time tests were performed and in these two cases (Nos 17 and $23)$ the MR percentage was 28 and $40 \%$ respectively. A monoclonal light chain pattern was identified in 24 cases $(88.8 \%)$. In two of the patients Nos 24 and 26, in whom light chains were not demonstrable, $\operatorname{Ig} \mu$ was present in the majority of cells ( 71 and $68 \%$ respectively). The remaining case had no demonstrable immunoglobulin.

The heavy chain results are summarised in Table 3. Ig $\mu$ was present in all but three cases and in two of these cases $\operatorname{Ig} \gamma$ was present, one of these two cases also showing the presence of Ig $\delta$. As mentioned above, the remaining Ig $\mu$ negative case did not show any immunoglobulin. The presence of $\operatorname{Ig} \delta$ was shown in 12 patients in association with $\operatorname{Ig} \mu$ alone in nine cases and other heavy chains in the remainder.

Table 2 Percentages of immunoglobulin-positive cells by the indirect immunoperoxidase reaction together with $E^{4}$ and $M$ rosette counts

\begin{tabular}{|c|c|c|c|c|c|c|c|c|c|c|c|}
\hline \multirow{2}{*}{$\begin{array}{l}\text { Patient } \\
\text { No }\end{array}$} & \multirow{2}{*}{$\begin{array}{l}\text { Sex and } \\
\text { age (yr) }\end{array}$} & \multirow{2}{*}{$\begin{array}{l}\text { Absolute } \\
\text { lymphocyte } \\
\text { count } \times \\
10^{9} / l\end{array}$} & \multirow{2}{*}{$\begin{array}{l}E^{4} \text { rosette } \\
\text { percentage }\end{array}$} & \multirow{2}{*}{$\begin{array}{l}\text { Mouse } \\
\text { rosette } \\
\text { percentage }\end{array}$} & \multicolumn{6}{|c|}{ Immunoglobulin-positive cells (\%) } & \multirow{2}{*}{$\begin{array}{l}\text { Treatment } \\
\text { status }\end{array}$} \\
\hline & & & & & $\kappa$ & $\lambda$ & $\mu$ & $\alpha$ & $\delta$ & $\gamma$ & \\
\hline $\begin{array}{r}1 \\
2 \\
3 \\
4 \\
5 \\
6 \\
7 \\
8 \\
9 \\
10 \\
11 \\
12 \\
13 \\
14 \\
15 \\
16 \\
17 \\
18 \\
19 \\
20 \\
21 \\
22 \\
23 \\
24 \\
25 \\
26 \\
27\end{array}$ & $\begin{array}{l}\text { F } 65 \\
\text { F } 61 \\
\text { F } 66 \\
\text { M 70 } \\
\text { F } 79 \\
\text { M } 55 \\
\text { M } 66 \\
\text { F } 80 \\
\text { F } 72 \\
\text { F } 75 \\
\text { M } 62 \\
\text { F } 54 \\
\text { M } 59 \\
\text { M } 44 \\
\text { M } 58 \\
\text { M } 74 \\
\text { F } 62 \\
\text { M } 68 \\
\text { M } 67 \\
\text { M } 60 \\
\text { M } 71 \\
\text { M } 61 \\
\text { F } 75 \\
\text { M } 72 \\
\text { M } 53 \\
\text { M } 54 \\
\text { M } 76\end{array}$ & $\begin{array}{c}18 \cdot 0 \\
11 \cdot 2 \\
10 \cdot 7 \\
5 \cdot 0 \\
19 \cdot 4 \\
76 \cdot 8 \\
18 \cdot 4 \\
41 \cdot 8 \\
93 \cdot 8 \\
53 \cdot 0 \\
13 \cdot 4 \\
39 \cdot 5 \\
44 \cdot 0 \\
62 \cdot 0 \\
17 \cdot 0 \\
39 \cdot 9 \\
3 \cdot 1 \\
5 \cdot 1 \\
390 \cdot 0 \\
9 \cdot 3 \\
30 \cdot 9 \\
5 \cdot 34 \\
2 \cdot 78 \\
86 \cdot 0 \\
116 \cdot 0 \\
9 \cdot 7 \\
12 \cdot 2\end{array}$ & $\begin{array}{r}6 \\
23 \\
23 \\
18 \\
28 \\
2 \\
9 \\
32 \\
2 \\
4 \\
23 \\
10 \\
4 \\
6 \\
3 \cdot 5 \\
10 \\
28 \\
26 \\
1 \\
29 \\
12 \\
21 \\
45 \\
0 \\
9 \\
38 \\
22\end{array}$ & $\begin{array}{r}39 \\
19 \\
23 \\
8 \\
46 \\
35 \\
29 \\
52 \\
29 \\
70 \\
8 \\
66 \\
40 \\
72 \\
50 \\
56 \\
28 \\
74 \\
72 \\
19 \\
74 \\
24 \\
40 \\
53 \\
80 \\
39 \\
30\end{array}$ & $\begin{array}{c}\overline{0} \\
64 \\
81 \\
70 \\
58 \\
- \\
70 \\
66 \\
67 \\
-\overline{1} \\
9 \overline{87} \\
- \\
- \\
- \\
- \\
100 \\
17 \\
- \\
- \\
\overline{6} \\
63 \\
- \\
51\end{array}$ & $\begin{array}{c}79 \\
79 \\
- \\
- \\
- \\
\overline{61} \\
- \\
- \\
\overline{5} \\
\overline{6} \\
65 \\
\overline{81} \\
79 \\
67 \\
75 \\
5 \overline{7} \\
66 \\
74 \\
- \\
- \\
- \\
\overline{0} \cdot 5\end{array}$ & $\begin{array}{l}94 \\
80 \\
- \\
80 \\
91 \\
50 \\
- \\
69 \\
76 \\
92 \\
70 \\
90 \\
69 \\
79 \\
72 \\
83 \\
80 \\
70 \\
99 \\
51 \\
50 \\
77 \\
- \\
71 \\
81 \\
68 \\
53\end{array}$ & $\begin{array}{l}6 \overline{9} \\
- \\
73 \\
- \\
- \\
- \\
- \\
- \\
- \\
- \\
- \\
- \\
- \\
- \\
- \\
- \\
0 \cdot 5 \\
- \\
- \\
4 \\
- \\
-\end{array}$ & $\begin{array}{r}36 \\
79 \\
- \\
60 \\
50 \\
\overline{41} \\
6 \\
\overline{71} \\
47 \\
49 \\
\overline{-} \\
- \\
\overline{39} \\
- \\
14 \\
- \\
- \\
- \\
- \\
- \\
- \\
6 \overline{6}\end{array}$ & $\begin{array}{r}- \\
51 \\
- \\
\overline{-} \\
30 \\
- \\
- \\
- \\
- \\
- \\
- \\
- \\
- \\
- \\
- \\
- \\
- \\
- \\
- \\
- \\
- \\
-\end{array}$ & $\begin{array}{l}\text { No treatment (NT) } \\
\text { NT } \\
\text { NT } \\
\text { Chlorambucil } \\
\text { NT } \\
\text { Chlorambucil, CVP* } \\
\text { NT } \\
\text { Chlorambucil } \\
\text { NT } \\
\text { NT } \\
\text { Chlorambucil, CVP* } \\
\text { NT } \\
\text { CVP* } \\
\text { NT } \\
\text { Chlorambucil } \\
\text { Chlorambucil } \\
\text { NT } \\
\text { Chlorambucil, CVP* } \\
\text { Chlorambucil } \\
\text { Chlorambucil, Prednisone } \\
\text { NT } \\
\text { Chlorambucil } \\
\text { NT } \\
\text { NT } \\
\text { Chlorambucil } \\
\text { NT } \\
\text { Chlorambucil }\end{array}$ \\
\hline
\end{tabular}

* Cyclophosphamide, vincristine and prednisone. 
Table 3 Summary of heavy chain isotypes found

\begin{tabular}{ll}
\hline Heavy chain present & No of patients \\
\hline $\operatorname{Ig} \mu$ & 13 \\
$\operatorname{Ig} \mu$ and $\delta$ & 9 \\
$\operatorname{Ig} \mu$ and $\delta$ and $\alpha$ & 2 \\
$\operatorname{Ig} \delta$ and $\gamma$ & 1 \\
$\operatorname{Ig} \gamma$ & 1 \\
None & 1 \\
\hline
\end{tabular}

Table 4 Percentages of positive cells in patient No 2 before and after trypsinisation and after incubation in Eagle's medium for 24 hours

\begin{tabular}{llllllll}
\hline & \multicolumn{6}{c}{$\begin{array}{l}\text { Percentage of positive cells with } \\
\text { antihuman }\end{array}$} \\
\cline { 2 - 7 } & $\kappa$ & $\lambda$ & $\mu$ & $\alpha$ & $\delta$ & $\gamma$ \\
\hline $\begin{array}{l}\text { Cytospin of cells before } \\
\text { trypsinisation }\end{array}$ & 0 & 79 & 81 & 60 & 82 & 0 \\
$\begin{array}{l}\text { Cytospin of cells after } \\
\text { trypsinisation }\end{array}$ & 0 & 76 & 73 & 83 & 77 & 0 \\
$\begin{array}{l}\text { Cytospin of cells after } \\
\text { incubation }\end{array}$ & 0 & 67 & 59 & 57 & 72 & 0 \\
\hline
\end{tabular}

$\operatorname{Ig} \alpha$ appeared to be present with other heavy chains in two patients.

The cells from patient No 2 reacted very strongly with anti $\lambda$ and strongly with anti $\operatorname{Ig} \mu, \delta$ and $\alpha$ antibodies. The results obtained by staining of cytospins made of her cells after trypsinisation and subsequent incubation, together with results prior to trypsinisation are shown in Table 4. There was no significant change in the number of positive cells after trypsinisation or incubation but the post-trypsinisation samples gave weaker results than the samples of pretrypsinised cells and post incubation cells.

The mean MR percentage for the group of cases showing Ig $\mu$ only was $48.8 \pm 19.53$ while that of the group with $\operatorname{Ig} \mu$ and $\operatorname{Ig} \delta$ was $47.89 \pm 23.37$ but the mean percentage in the four cases showing $\operatorname{Ig} \alpha$ or $\gamma$ chains was $19.75 \pm 8 \cdot 8$. The difference in MR percentage between this group and the combined $\operatorname{Ig} \mu$ and $\operatorname{Ig} \mu+\delta$ groups is statistically significant ( $<<0.05$ Mann Whitney U test). Two of the group showing $\operatorname{Ig} \alpha$ or $\gamma$ chains (cases $2 \& 4$ ) reacted strongly with antisera indicating the presence of large amounts of immunoglobulin while the cells of the other two patients showed weaker staining. The morphology of the lymphocytes in three of these cases was unremarkable while in one case (No 7) the lymphocytes appeared less mature but had weakly staining immunoglobulins, and the current survival of the four cases ranges from 4 to $9 \mathrm{yr}$.

\section{Discussion}

This study demonstrates that immunoperoxidase labelled antibodies may be used for immunoglobulin demonstration in B-CLL if Baker's formol calcium
Markey, McConnell, Alexander, Morris, Robertson

is used as a fixative. The results, with demonstration of light chain monoclonality in $88 \%$ of cases, are comparable to reported results $\left(71 \%,{ }^{9} 81 \%{ }^{10}\right)$ of surface immunoglobulin light chain monoclonality using fluorochrome labelled antibodies and live cells. A monoclonal heavy chain pattern was demonstrated in $85 \%$ of cases with either a single heavy chain ( $\operatorname{Ig} \mu$ or $\gamma$ ) or a combination of $\operatorname{Ig} \mu$ and $\operatorname{Ig} \delta$ being present. The simultaneous presence of $\operatorname{Ig} \mu$ and $\operatorname{Ig} \delta$ in cells is not at variance with current concepts of monoclonality as their coexistence is acceptable as part of the ontogenetic switch mechanism. ${ }^{11}$ Only two patients (Nos 2 and 4) showed the presence of a heavy chain in addition to $\operatorname{Ig} \mu$ and $\operatorname{Ig} \delta$ and the reactions obtained with each heavy chain antiserum appeared equally strong. This was not due to the presence of adsorbed immunoglobulins $\vec{N}$ remaining on the cell surfaces as the light chains $\vec{\omega}$ present in each case were clearly monoclonal. Laur- $\underset{\omega}{0}$ ent $e t a l^{2}$ have suggested the presence of minor 0 unwanted specificities in the anti-immunoglobulin antisera as an explanation for such cases, but we are $\vec{\nabla}$ unwilling to accept this in these two cases because of $\mathbb{D}$ the equivalent strength of reaction obtained with each antiserum combined with the negative results $\frac{3}{0}$ in the rest of the B-CLL cases and the strong reactions with single antisera in the control myeloma and $\overrightarrow{0}$ lymphoma cells. As the great majority of norma perinatal B lymphoid cells simultaneously exhilit the presence of three heavy chain isotypes-that $\operatorname{Ig} \mu$ and $\operatorname{Ig} \delta$ and either $\operatorname{Ig} \gamma$ or $\operatorname{Ig} \alpha,{ }^{11}$ it would not be surprising that some cases of B-CLL might have a similar phenotype. Moreover, in a study of surface $\mathbb{\perp}$ immunoglobulins by IF in a series of 230 cases, $\stackrel{\varrho}{\vec{P}}$ Reijden et $a^{12}$ found three similar cases.

It was not possible in this study to differentiate between surface and cytoplasmic location of the immunoglobulin demonstrated. Reitamo et $\mathrm{al}^{13}$ demonstrated that use of Baker's formol calcium permitted the immunostaining of immunoglobulins in myeloma cells and our own results with myeloma and lymphoma cells, the staining of intracellular $\delta$ inclusions and the continuing though weaker positiv- 3 ity after trypsinization indicate that cytoplasmic 의 immunoglobulin is contributing to the end result in $\rightarrow$ our cases. Until recently cytoplasmic immunoglobulin had not been detected in B-CLL but Han et $a l^{14} \mathrm{~N}$ demonstrated its presence by immunofluorescent os techniques in each of 20 cases of B-CLL using $N$ acetone fixation for $5 \mathrm{~min}$ and Newell et al ${ }^{15}$ using $\underset{\omega}{\mathrm{\omega}}$ peroxidase labelled antibodies and glutaraldehyde $\bar{\sigma}$ fixed cells also demonstrated cytoplasmic mono-o clonal immunoglobulin at EM level. Nevertheless, the accentuation of staining which we commonly? find at the periphery of the cell and the weakening of $\square$ staining after trypsinisation with subsequent streng- 
thening after incubation suggests that surface immunoglobulin is also contributing to our end result.

The choice of fixative and length of fixation is known to be crucial for subsequent identification of immunoglobulin. Mason et al ${ }^{16}$ investigated a wide variety of fixatives in their original description of the use of immunoperoxidase labelled antibodies in a peroxidase antiperoxidase system for immunoglobulin identification and found that $30 \mathrm{~s}$ fixation in buffered formol acetone gave the best results for surface immunoglobulin in lymphoma cells, but when using this fixative in CLL only five of 28 cases gave positive results (three membrane like, two cytoplasmic inclusions). ${ }^{1}$ Reitamo et $\mathrm{al}^{13}$ also investigated different fixatives for immunoglobulin identification in cytospin preparations of plasma cells and pokeweed mitogen stimulated lymphocytes and found that two to four minutes fixation in Baker's formol calcium gave the best preservation of immunoglobulin antigenicity. Buffered formol acetone permitted detection of intracellular immunoglobulin in plasma cells but not in pokeweed mitogen stimulated lymphocytes and they concluded that the lower amount of intracellular immunoglobulin in the mitogen stimulated cells might be more easily destroyed by the fixative. We believe that it is the use of Baker's formol calcium which is largely responsible for our success in this series and we agree that the length of fixation time is critical as increase of this time to even six minutes diminishes positivity. Preliminary observations (unpublished) also suggest that omission of the methanol-hydrogen peroxide step for blocking endogenous peroxidase (which is unnecessary when dealing with washed predominantly lymphocytic cells) enhances positivity. We have found this fixation procedure also to be excellent for identification of many $T$ cell antigens in air dried lymphocytes either in cytospin preparations or in touch preparations from tissues. ${ }^{17}$

The positive correlation shown between the presence of later immunoglobulin chains-that is, $\operatorname{Ig} \alpha$ or Ig $\gamma$ and low MR albeit in such a small group of cases is interesting. As the ability to produce $\operatorname{Ig} \gamma$ or $\operatorname{Ig} \alpha$ chains occurs later in developing lymphocytes than the ability to produce $\operatorname{Ig} \mu$ or $\delta,{ }^{11}$ it is not surprising to find a corresponding decrease in capacity for MR formation, a function which diminishes with increasing lymphocyte maturity, in such cells. Koziner et al ${ }^{9}$ also found a decrease in MR when heavy chains other than $\operatorname{Ig} \mu$ were found and this was most marked in cases with $\operatorname{Ig} \gamma$ or $\operatorname{Ig} \alpha$ on their cells. In contrast to their findings, however, we did not find any difference in MR between $\operatorname{Ig} \mu$ and $\operatorname{Ig} \mu+\delta$ groups. Catovsky et $a l^{10}$ have shown a correlation between prolymphocytic leukaemia and low MR but the indolence of the disease in our four patients rules out the possibility of this diagnosis in our cases.

The advantages of immunoperoxidase methods as compared to immunofluorescent methods for diagnostic work have been detailed in several publications and include: $:^{1-3}$

(i) use of standard microscopical equipment;

(ii) simultaneous morphological identification of positively staining cells in mixed cell populations provided by routine haematological counterstaining;

(iii) permanence of results.

A most important additional advantage is the degree of control which this procedure permits because storage of multiple cytospins allows daily incorporation of positive and negative control cells for each antibody being used. This is generally not feasible in live cell testing by immunofluorescence. Moreover, relatively few cells are needed for each cytospin, so it is possible to test for the presence of at least 20 antigens with a meagre $1 \times 10^{6}$ cells which would only allow one antibody to be used if a live cell method were being used. While this may be relatively unimportant in CLL where large numbers of cells are present, it can be critical when studying cell suspensions from tissues in lymphoma where sometimes very few neoplastic cells may be obtained. In addition, due to lack of Fc binding in fixed cells, ${ }^{18}$ ultracentrifugation of anti-serum and use of $\mathrm{F}(\mathrm{ab})_{2}$ fragment antibodies becomes unnecessary. The ease, accuracy and speed of interpretation of results obtained by this method are also advantages not to be lightly dismissed. In conclusion we consider that this method for immunoglobulin identification in B-CLL is accurate and sensitive, capable of day-today control and offers many advantages over immunofluorescent methods.

The authors wish to thank Mrs Deirdre Glen and Miss Diane Barker for typing the manuscript.

\section{References}

' Mason DY, Leonard RCF, Laurent G, Gourdin MF. Immunoperoxidase staining of surface and intracellular immunoglobulin in human neoplastic lymphoid cells. J Clin Pathol 1980;33:609-16.

${ }^{2}$ Laurent G, Gourdin MF, Reyes F. Immunoperoxidase detection of immunoglobulins in cells of immunoproliferative diseases. Am J Clin Pathol 1980;74:265-74.

${ }^{3}$ Knowles DM, Winchester RJ, Kunkel HG. A comparison of peroxidase and fluorochrome conjugated antisera for the demonstration of surface and intracellular antigens. Clin Immunol Immunopathol 1977;7:410-25.

4 WHO/IRAC Sponsored workshop on Human B \& T cells. Scand J Immunol 1974;3:521. 
1396

${ }^{5}$ Stathopoulos G, Elliott EV. Formation of mouse or sheep red blood cell rosettes by lymphocytes from normal and leukaemic individuals. Lancet 1974; i:600-1.

${ }^{6}$ Mason DY, Labaume S, Preud'homme JL. The detection of membrane and cytoplasmic immunoglobulins in human leucocytes by immunoperoxidase staining. Clin Exp Immunol 1977;29:413-21.

${ }^{7}$ Preud' homme JL, Seligmann M. Immunoglobulins on the surface of lymphoid cells in Waldenstrom's macroglobulinaemia. $J$ Clin Invest 1972;51:701-5.

${ }^{8}$ Graham RC Jr, Lundholm U, Karnovsky MJ. Cytochemical demonstration of peroxidase activity with 3 amino 9 ethylcarbazole. J Histochem Cytochem 1965;13:150-2.

${ }^{9}$ Koziner B, Kempin S, Passe S, Gee T, Good RA, Clarkson BD. Characterisation of $B$ cell leukaemias: a tentative immunomorphological scheme. Blood 1980;56:815-23.

${ }^{10}$ Catovsky D, Pitman S, O'Brien M, et al. Multiparameter studies in lymphoid leukaemias. Am J Clin Pathol 1979;72:736-45.

" Gathings WE, Kubagawa H, Cooper MD. A distinctive pattern of B cell immaturity in perinatal humans. Immunol Rev 1981;57:107-26.

${ }^{12}$ Reijden HJ, Gaag R, Pinkster J, Rumke H, Veer MB, Melief CJ, Borne AE. Chronic lymphocytic leukaemia: Immunologic markers and functional properties of the leukaemic cells. Cancer 1982;50:2826-33.
Markey, McConnell, Alexander, Morris, Robertson

${ }^{13}$ Reitamo SR, Ranki A, Kinttinen YT, Hayry P. Immunoperoxidase identification of intracellular immunoglobulins from cell smears. Am J Clin Pathol 1980;73:248-9.

${ }^{14}$ Han T, Ozer H, Bloom M, Sagawa K, Minowada J. The presence of monoclonal cytoplasmic immunoglobulins in leukaemic B cells from patients with chronic lymphocytic leukaemia. Blood 1982;59:435-8.

${ }^{15}$ Newell DG, Hannam-Harris A, Smith JL. The ultrastructural localisation of immunoglobulin in chronic lymphocytic lymphoma cells: changes in light and heavy chain distribution induced by mitogen stimulation. Blood 1983;61:511-9.

${ }^{16}$ Mason DY, Farrell C, Taylor CR. The detection of intracellular antigens in human leucocytes by immunoperoxidase staining. Br J Haematol 1975;31:361-70.

${ }^{17}$ Markey GM, Alexander HD, Morris TCM, Robertson JH. A rapid method for identification of surface antigens on fixed cells using monoclonal antibodies. J Clin Pathol 1982;35:1295-6.

${ }^{18}$ McKeever PE, Garvin AJ, Spicer SS. Immune complex receptors on cell surfaces 1 . Ultrastructural demonstration on macrophages. J Histochem Cytochem 1976;24:948-55.

Requests for reprints to: Dr Geraldine Markey, Haematology Department, The Laboratories, Belfast City Hospital, Lisburn Road, Belfast BT9 8AB, N Ireland. 